\title{
MULTIPLICAÇÃO in vitro DA AMOREIRA-PRETA 'ÉBANO' EM DIFERENTES CONCENTRAÇÕES DE MEIO MS E BAP
}

\author{
In vitro multiplication of blackberry (Rubus sp.) 'ÉBANO' \\ in diferents MS medium concentrations and BAP
}

Fabíola Villa ${ }^{1}$, Aparecida Gomes de Araújo ${ }^{2}$, Leila Aparecida Salles Pio ${ }^{3}$, Moacir Pasqual ${ }^{4}$

\begin{abstract}
RESUMO
A micropropagação da amoreira-preta pode gerar plantas livres de vírus e em curto espaço de tempo. Com o objetivo de aprimorar técnicas de propagação in vitro de amoreira-preta (Rubus sp.), testaram-se concentrações de meio MS e BAP. Gemas axilares com cerca de $2 \mathrm{~cm}$, de plântulas pré-estabelecidas in vitro da cultivar Ébano, oriunda da Embrapa Clima Temperado/CPACT-Pelotas, RS, foram excisadas e inoculadas em meio MS (0, 50, 100, 150 e 200\%), suplementado com concentrações de BAP $\left(0 ; 0,5 ; 1,0 ; 2,0\right.$ e 4,0 $\left.\mathrm{mg} \mathrm{L}^{-1}\right)$. O experimento foi inteiramente casualizado, utilizando-se de três explantes por repetição. $\mathrm{O}$ pH do meio foi ajustado para 5,8 antes da adição de $6 \mathrm{~g} \mathrm{~L}^{-1}$ de ágar e da autoclavagem a $121^{\circ} \mathrm{C}$ e 1 atm por 20 minutos. Após a inoculação, os explantes foram mantidos por 60 dias em sala de crescimento a $27 \pm 1^{\circ} \mathrm{C}$, irradiância de $35 \mu \mathrm{M}$.m ${ }^{-}$ ${ }^{2} \cdot \mathrm{s}^{-1}$ e fotoperíodo de 16 horas, avaliando-se número de folhas, número e comprimento dos brotos, número de raízes, peso da matéria fresca e seca da parte aérea. Melhores resultados foram obtidos em meio MS 150\%, em que foi observado maior número de folhas $(7,89)$ e de brotos $(3,99)$, acrescidos de $1 \mathrm{mg} \mathrm{L}^{-1}$ de BAP. Na ausência de reguladores de crescimento, o número de raízes apresentou melhor desenvolvimento, sem a formação de calos.
\end{abstract}

Termos para indexação: Rubus sp., BAP, meio de cultura MS.

\begin{abstract}
With the objective to micropropagation the blackberry (Rubus sp.), cv. Ébano, nodal segments of plants in vitro, originated from Embrapa Clima Temperado/CPACT-Pelotas, RS, were inoculated in MS culture medium (0, 50, 100, 150 and 200\%), suplemented with different BAP concentrations (0; 0,5; 1,0; 2,0 and 4,0 $\mathrm{mg} \mathrm{L}^{-1}$ ). The pH was adjusted for 5,8 before adding $6 \mathrm{~g} \mathrm{~L}^{-1}$ agar and before the esterilization at $121^{\circ} \mathrm{C}$ and $1 \mathrm{~atm}$ for 20 minutes. After the inoculation, the explants were maintained by 60 days, in growth room, $27 \pm 1^{\circ} \mathrm{C}, 35 \mu \mathrm{M} \mathrm{m}^{-2} \mathrm{~s}^{-1}$ and photoperiod 16 hours. The experiment was randomized complete blocks, using three explants by repetition. Better results were obtained with $150 \%$ MS medium, where the largest number $(7,89)$ and sprouts $(3,99)$ were observed, added of $1 \mathrm{mg} \mathrm{L}^{-1}$ de BAP. In the absence of BAP the number of roots had presented better development, without the callus's formation.
\end{abstract}

Index terms: Rubus sp., BAP, culture medium MS.

(Recebido para publicação em 2 de abril de 2004 e aprovado em 12 de abril de 2005)

\section{INTRODUÇÃO}

No Brasil, a amoreira-preta vem sendo cultivada por pequenos produtores do Rio Grande do Sul (principal produtor brasileiro), Santa Catarina e Paraná, objetivando a exportação dos frutos. No Rio Grande do Sul, as maiores produções encontram-se nos municípios de Feliz e Vacaria, onde a cultivar Tupy responde por 70\% da área cultivada, com produção a partir da terceira dezena de novembro (ANTUNES, 1999). O sul de Minas Gerais tem apresentado elevado potencial para essa pequena fruta, destacando-se o município de Caldas.

A cultivar Ébano foi selecionada em 1977, na antiga UEPAE de Cascata e lançada em 1981 pela Embrapa/ Centro de Pesquisa Agropecuária de Clima Temperado, Pelotas -RS, sendo livre de espinhos (BASSOLS \& MOORE, 1981; RASEIRA et al., 1984).

A sua propagação se faz por meio de estacas de raízes (CALDWELL, 1984) que, por ocasião do repouso vegetativo, são preparadas e enviveiradas em sacolas plásticas. Podem também ser usados brotos (rebentos) originados de plantas cultivadas e estacas herbáceas (REZENDE, 1996). Além desses, a micropropagação, com o intuito de se obterem plantas livres de vírus, geneticamente uniformes e em curto espaço de tempo, é uma alternativa viável (SKIRVIN et al., 1981).

\footnotetext{
1. Mestranda em Fitotecnia - Departamento de Agricultura/DAG - Universidade Federal de Lavras/UFLA - Caixa Postal 3037 - 37.200-000 Lavras,MG -fvilla@virgilio.it

2. Doutoranda em Fitotecnia - DAG/UFLA

3. Mestre em Fitotecnia - DAG/UFLA.

4. Prof. Dr. Titular do Departamento de Agricultura/UFLA.
} 
Vários autores têm relatado a possibilidade de reduzir a concentração de sais do meio MS, para diversas espécies, visando ao melhor desenvolvimento das plantas e redução nos custos (GEORGE \& SHERRINGTON, 1984). Paiva et al. (1997a) utilizaram $50 \%$ dos sais do meio MS obtendo um bom desenvolvimento in vitro de gloxínia. Concentrações de sais no meio básico MS (MURASHIGE \& SKOOG, 1962) reduzidas a $1 / 2,1 / 3$ ou $1 / 4$ possibilitaram melhor enraizamento in vitro de amoreira-preta, cultivar Caiguangue (DANTAS et al., 2000).

Um dos objetivos da micropropagação é a maximização da multiplicação de gemas. Muita atenção para sua obtenção tem sido dada com a manipulação de substâncias de crescimento no meio de cultura (BROJWANI et al., 1984; LEE \& KO, 1984). O crescimento e a morfogênese in vitro são fatores regulados pela interação e balanço dos reguladores de crescimento existentes no meio de cultura, principalmente auxinas e citocininas (GEORGE \& SHERRINGTON, 1984).

As citocininas são utilizadas para quebra da dormência apical dos brotos e aumento da taxa de multiplicação. Desse modo, ocorre um grande número de brotações por meio do crescimento de meristemas laterais (SRISKANDARAJAH et al., 1982).

Dentre os reguladores de crescimento comumente usados no cultivo in vitro da amoreira-preta, estão a 6benzilaminopurina (BAP) e o ácido indol butírico (AIB) (DONNELLY et al., 1980). Broome \& Zimmerman (1978), por exemplo, obtiveram uma rápida proliferação de brotos a partir de gemas axilares das cultivares 'Smothstem' e 'US 64-39-2', com o emprego de 1,0 mg L' ${ }^{1}$ de BAP + 0,1 $\mathrm{mg} \mathrm{L}^{-1}$ de $\mathrm{GA}_{3}+1,0 \mathrm{mg} \mathrm{L}^{-1}$ de AIB.

Com o presente trabalho objetivou-se avaliar o efeito de concentrações de benzilaminopurina (BAP) e do meio MS na multiplicação in vitro de amoreira-preta, cultivar Ébano.

\section{MATERIAL E MÉTODOS}

Segmentos nodais de amoreira-preta, cultivar 'Ébano', com cerca de $2 \mathrm{~cm}$, foram excisados de plântulas preestabelecidas in vitro oriundas da Embrapa Clima Temperado/CPACT-Pelotas, RS. Os explantes foram inoculados em tubo de ensaio contendo $15 \mathrm{ml}$ de meio constituído dos sais minerais do meio MS $(0,50$, 100, 150 e 200\%), combinados com cinco concentrações de BAP $\left(0 ; 0,5 ; 1,0 ; 2,0\right.$ e $\left.4,0 \mathrm{mg} \mathrm{L}^{-1}\right)$. O $\mathrm{pH}$ foi ajustado para 5,8, antes da autoclavagem e solidificado com $6 \mathrm{~g} \mathrm{~L}^{-1}$ de ágar da marca Merck ${ }^{\circledR}$. Posteriormente, foram transferidos para sala de crescimento a $27 \pm 1^{\circ} \mathrm{C}$, irradiância de $35 \mu \mathrm{M} \cdot \mathrm{m}^{-2} \cdot \mathrm{s}^{-1}$ fornecida por tubos fluorescentes de $20 \mathrm{~W}$, marca OSRAM $^{\circledR}$, luz do dia especial e fotoperíodo de 16 horas, permanecendo nessas condições por 60 dias.

$\mathrm{O}$ delineamento experimental utilizado foi $\mathrm{o}$ inteiramente casualisado com quatro repetições constituídas de três explantes. As variáveis analisadas foram número de folhas, número e comprimento dos brotos, número de raízes, peso da matéria fresca e seca da parte aérea.

Os resultados foram submetidos à análise de variância (FERREIRA, 2000), sendo utilizada regressão polinomial para concentrações de BAP e meio MS.

\section{RESULTADOS E DISCUSSÃO}

O número de folhas da cultivar Ébano foi estimulado pelo aumento da concentração de sais de MS e da citocinina BAP (Figura 1), observando a interação entre esses dois fatores.

Maior número de folhas $(7,89)$ foi observado no meio MS $150 \%$ e $1,0 \mathrm{mg} \mathrm{L}^{-1}$ de BAP.

Com o aumento dos níveis de BAP, pode-se constatar que houve decréscimo no número de folhas. Resultados semelhantes foram obtidos por Oliveira (1994), trabalhando com crisântemo, que observou queda no número de folhas com aumento das concentrações de BAP. Isso pode ser atribuído ao fato de o regulador de crescimento BAP estimular a formação de maior número brotos, porém, de tamanho reduzido, apresentando menor número de segmentos nodais e folhas.

O número de brotos da cultivar Ébano foi estimulado pelo aumento da concentração de sais de MS e da citocinina BAP (Figura 2), porém, não houve interação entre esses dois fatores. Maior número de brotos $(3,99)$ foi observado em meio MS 150\%, divergindo de Naves (2001), que verificou em trabalho com bromélia-imperial um aumento no tamanho dos brotos até a concentração de 100\% do meio MS. Em trabalho com café 'Catuaí', objetivando determinar o efeito de diferentes proporções dos sais inorgânicos e componentes orgânicos do meio MS, Forni \& Pasqual (1996) observaram que o aumento dos níveis de MS proporcionou maior número de brotos, número de folhas e peso da matéria seca.

Rápida proliferação de gemas axilares de amoreira-preta, cultivares Thornless Boysenberry e Thornless Youngberry, foi obtida em meio MS acrescido de 2,0 $\mathrm{mg} \mathrm{L}^{-1}$ de BAP e 0,1 $\mathrm{mg} \mathrm{L}^{-1}$ de ANA (SKIRVIN et al., 1981). O enraizamento desses brotos deu-se em meio MS (1/16 da concentração), independentemente da adição de reguladores de crescimento. 
VILLA, F. et al.

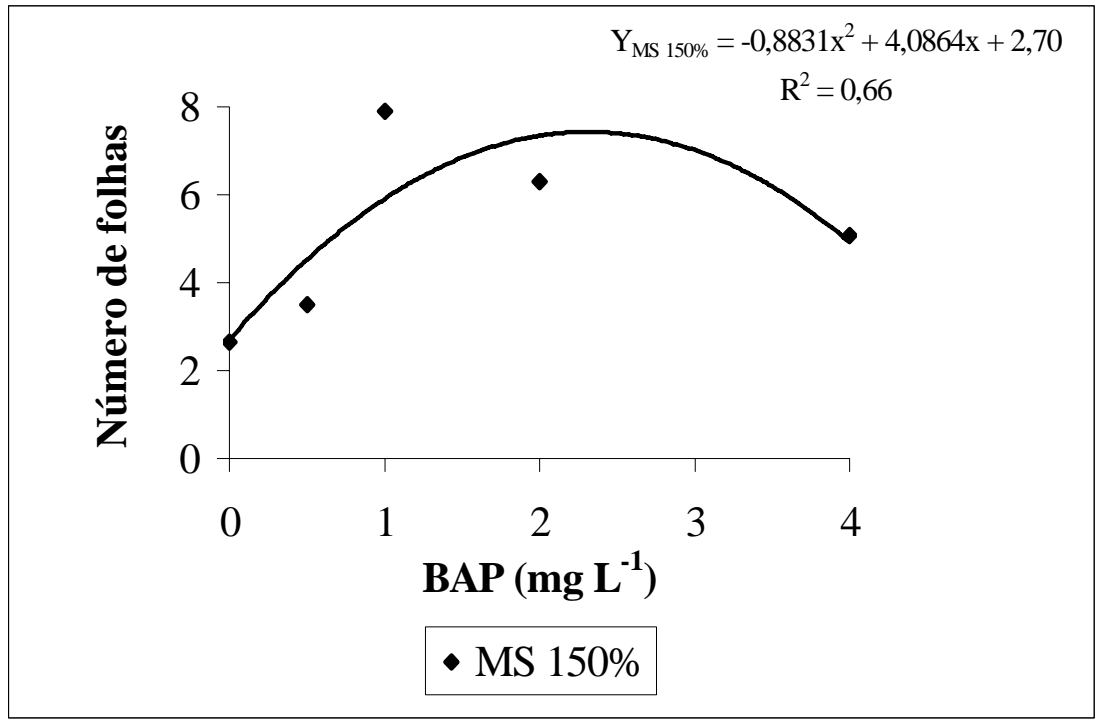

FIGURA 1 - Número de folhas em plântulas de amoreira-preta, cultivar Ébano, cultivadas em diferentes concentrações de BAP. UFLA, Lavras - MG, 2003.

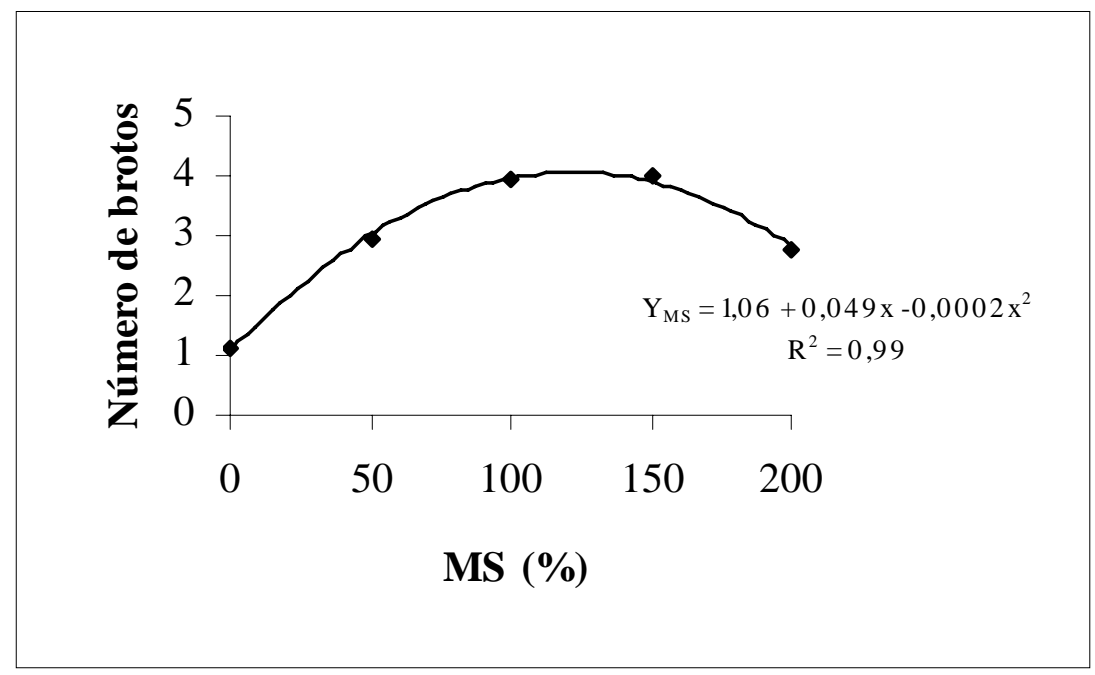

FIGURA 2 - Número de brotos em plântulas de amoreira-preta, cultivar Ébano, em diferentes concentrações de MS, respectivamente. UFLA, Lavras - MG, 2003. 
Castro et al. (2003), estudando a multiplicação in vitro de Limonium brasiliensis, verificou que o meio MS e 50\% MS sem a presença de BAP revelou-se significativo para a variável número de brotações por explante, alcançando ambos valores médios de 2,3, mostrando assim que a diferença de concentração de sais do meio MS em até $50 \%$ pode ser útil à redução dos custos de produção comercial dessas mudas.

Maior comprimento de brotos $(2,83 \mathrm{~cm})$ foi observado em meio MS 50\%, com 0,5 $\mathrm{mg} \mathrm{L}^{-1}$ de BAP, e na ausência dessa citocinina no meio MS $150 \%$, houve um comprimento de brotos de $3,79 \mathrm{~cm}$ (Figura 3).
Com o aumento das concentrações de BAP, houve diminuição no comprimento dos brotos. Esses resultados concordam com a maioria dos autores, que afirmam que esse regulador de crescimento não é responsável pelo alongamento de brotos (EARLE \& LANGHANS, 1974; PAIVA et al., 1997b; TAIZ \& ZEIGER, 1991).

Paiva (1997a), trabalhando com gloxínia, observou também uma redução do tamanho de brotos com o aumento das concentrações de BAP e alguns autores têm observado os mesmos resultados negativos desse regulador de crescimento no alongamento das brotações em espécies como crisântemo e morangueiro (OLIVEIRA, 1994; PASQUAL et al., 2002).

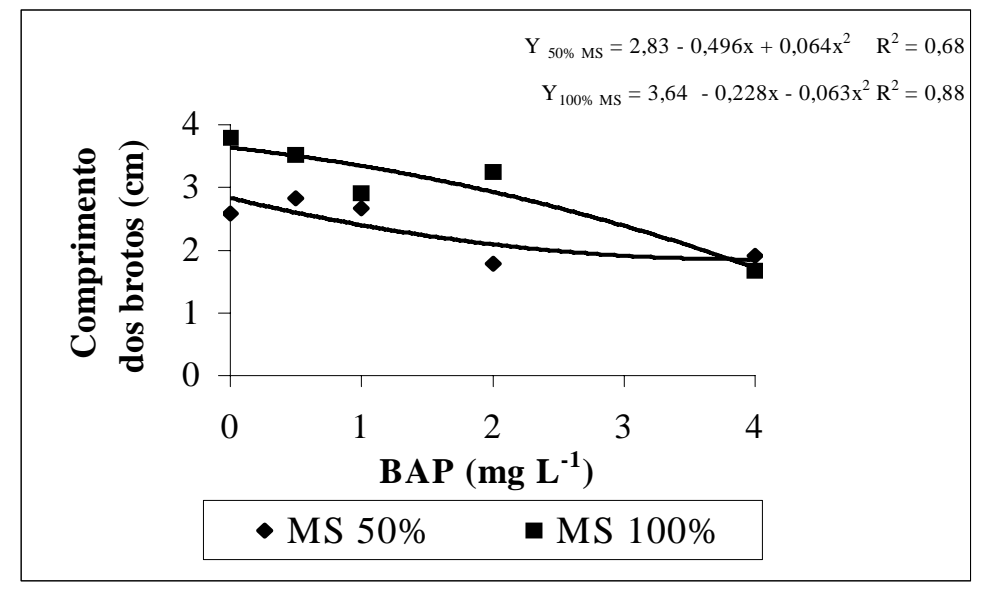

FIGURA 3 - Comprimento dos brotos de plântulas de amoreira-preta, cultivar Ébano, cultivadas em diferentes concentrações de BAP e do meio MS. UFLA, Lavras - MG, 2003.

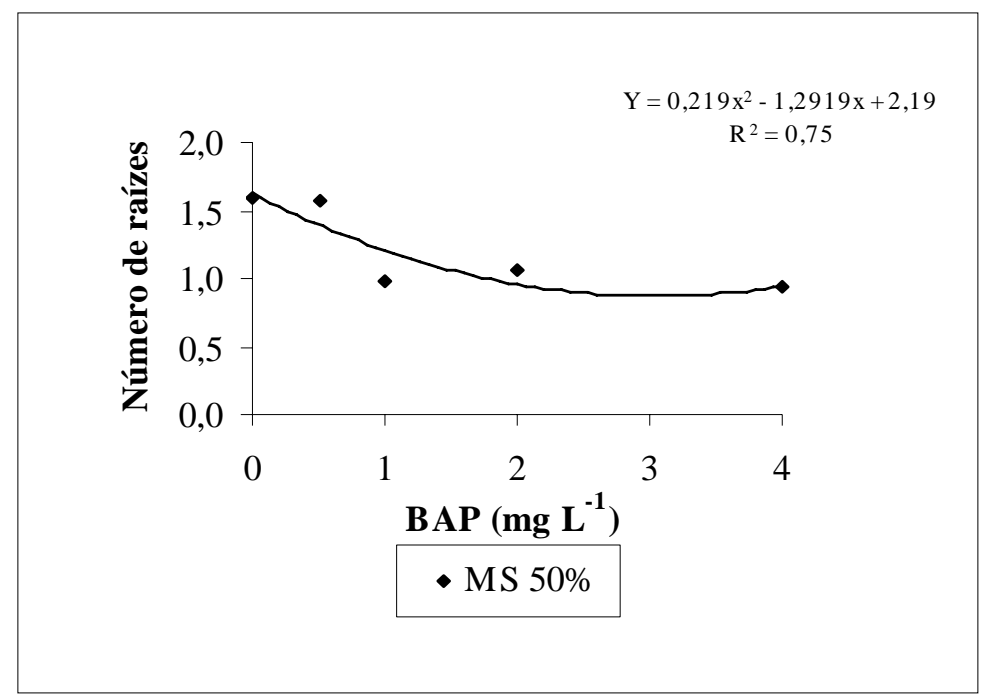

FIGURA 4 - Número de raízes de plântulas de amoreira-preta, cultivar Ébano, cultivadas em diferentes concentrações de BAP e do meio MS. UFLA, Lavras - MG, 2003. 
Houve interação entre BAP e meio MS para número de raízes, em que maior número $(1,6)$ foi verificado na ausência de BAP em meio MS 50\%. Os meios MS 0\%, 100\%, 150\% e 200\% não foram significativos. Com $4 \mathrm{mg} \mathrm{L}^{-1}$ de BAP, houve um menor número de raízes $(0,93)$.

Os resultados apresentados são diferentes dos resultados obtidos por Grattapaglia et al. (1987), em diversas espécies de Eucalyptus, onde existe uma correlação negativa entre o aumento das concentrações de BAP no meio de multiplicação e o número de raízes na fase de enraizamento in vitro. Oliveira (1994) observou que, em plantas de crisântemo, o aumento das concentrações de BAP provocou diminuição do número de raízes.

$\mathrm{O}$ peso da matéria fresca da parte aérea foi estimulado pelo aumento da concentração de sais de MS e de BAP (Figura 4A e 4B), porém, não houve interação entre esses dois fatores. Maior peso da matéria fresca da parte aérea $(1,52 \mathrm{~g})$ foi observado no meio MS 150\% e com $1 \mathrm{mg} \mathrm{L}^{-1}$ de BAP (1,03 g).

Com um aumento significativo do peso da matéria fresca no decorrer do tempo, o potencial osmótico do meio foi maior. Conseqüentemente, as plantas nesse meio conseguiram absorver mais água para os seus tecidos e, portanto, tiveram maior peso da matéria fresca.
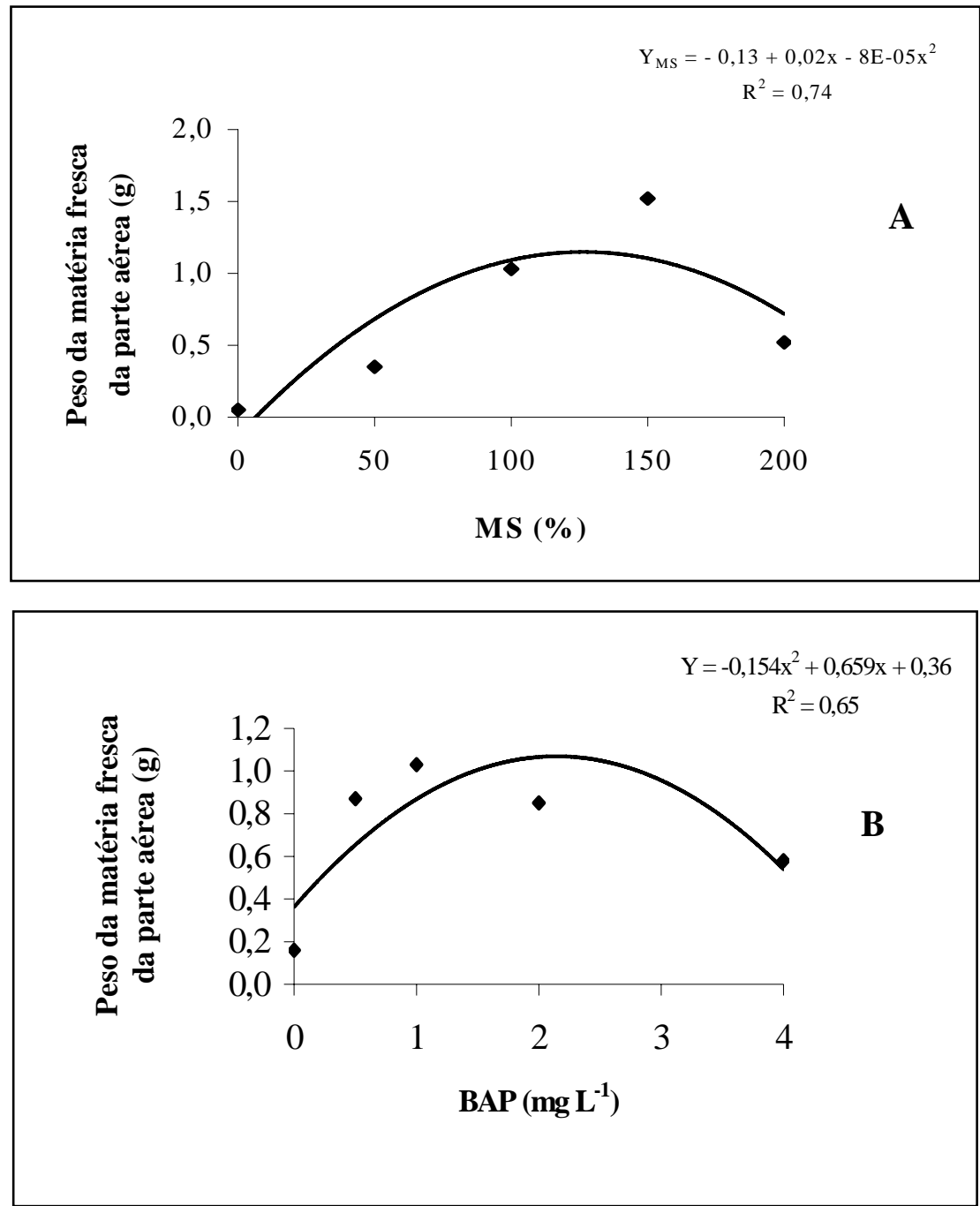

FIGURAS 4A e 4B - Peso da matéria fresca da parte aérea de plântulas de amoreira-preta, cultivar Ébano, cultivadas em diferentes concentrações do meio MS e BAP. UFLA, Lavras - MG, 2003. 
Os valores de todas as variáveis analisadas foram incrementados à medida que se aumentou a concentração do meio de cultura MS até um ponto máximo, a partir do qual se verificou decréscimo.

O peso da matéria seca da parte aérea, que é a expressão do crescimento real da parte aérea, atingiu o valor máximo com a utilização de 1 mg. $\mathrm{L}^{-1}$ de BAP e, a partir desse ponto, o regulador de crescimento BAP passou a inibir o desenvolvimento das plantas in vitro, apresentando um decréscimo no peso da matéria seca total (Figura 5).

Maior peso seco da matéria fresca foi verificado em $150 \%$ do meio MS, e, a partir de $200 \%$ do meio MS, houve um decréscimo do peso (Figura 5). É importante ressaltar que o meio MS possui alta concentração de sais em sua composição, quando comparado a outros meios de cultura (SAKUTA, 1987). Dessa forma, os efeitos negativos causados por concentrações maiores do meio MS provavelmente são devidos a uma elevação ainda maior do que a normalmente presente na composição original, tornando-se inadequada ao processo morfogênico (PASQUAL et al., 2002).

De maneira geral, a concentração adequada de BAP foi de até $1 \mathrm{mg} \mathrm{L}^{-1}$.

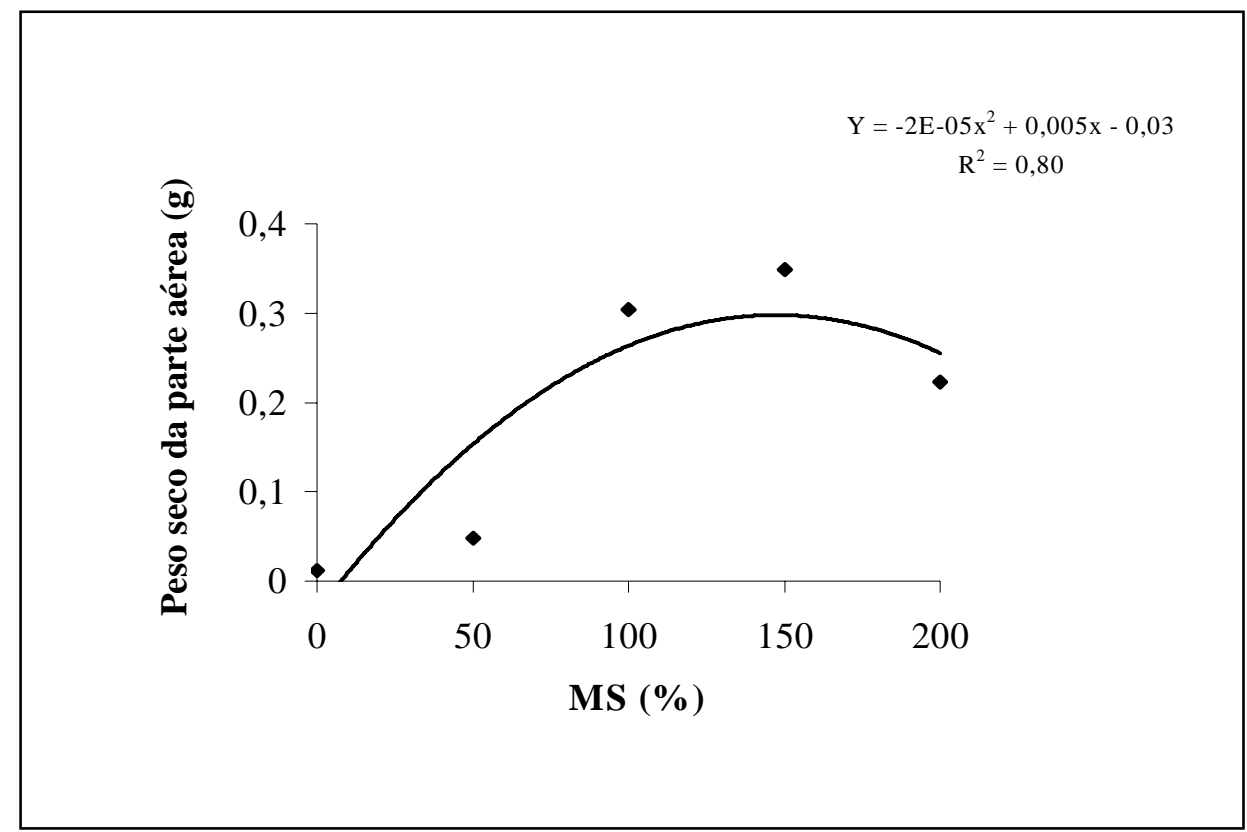

FIGURA 5 - Peso da matéria seca da parte aérea de plântulas de amoreira-preta, cultivar Ébano, cultivadas em diferentes concentrações do meio MS e BAP. UFLA, Lavras - MG, 2003.

\section{CONCLUSÕES}

A utilização de $1 \mathrm{mg} \mathrm{L}^{-1}$ de BAP promove a multiplicação in vitro de amoreira-preta, cultivar Ébano.

Maior número de folhas, brotos e comprimento da parte aérea foram obtidos em $150 \%$ do meio MS.

$\mathrm{Na}$ ausência de reguladores de crescimento, o número de raízes apresentou melhor desenvolvimento, sem a formação de calos.

Maior peso da matéria seca total foi obtido na presença de $1 \mathrm{mg} \mathrm{L}^{-1}$ de BAP e $150 \%$ do meio MS.

\section{REFERÊNCIAS BIBLIOGRÁFICAS}

ANTUNES, L. E. C. Aspectos fenológicos, propagação e conservação pós-colheita de frutas de amoreira-preta (Rubus spp) no sul de Minas Gerais. 1999. 129 p. Tese (Doutorado em Fitotecnia) Universidade Federal de Lavras, Lavras, 1999.

BASSOLS, M. C.; MOORE, J. N. Ébano thornless blackberry. HortScience, Alexandria, v. 16, n. 5, p. 686-687, 1981. 
BHOJWANI, S. S.; MULLINS, K.; COHEN, D. In vitro propagation of Pyrus pyrifolia. Scientia Horticulturae, Amsterdam, v. 23, p. 247-254, 1984.

BROOME, O. C.; ZIMMERMAN, R. H. In vitro propagation of blackberry. HortScience, Alexandria, v. 13, n. 2, p. 151-153, 1978.

CALDWELL, J. D. Blackberry propagation. HortScience, Alexandria, v. 19, n. 2, p. 193-195, 1984.

CASTRO, K. G. da S. de; SCHUCH, M. W.; BRAGA, E. J. B. Multiplicação in vitro de Limonium brasiliensis (BOISS.) Kuntze: diferentes concentrações de BAP e sais minerais no meio de cultura. In: CONGRESSO BRASILEIRO DE FLORICULTURA E PLANTAS ORNAMENTAIS, 14.; CONGRESSO BRASILEIRO DE CULTURA DE TECIDOS DE PLANTAS, 1., 2003, Lavras. Anais... Lavras: UFLA, 2003. p. 132.

DANTAS, M. C. A.; CERETTA, M.; COUTINHO, F. E.; FORTES, G. R. de L. Enraizamento in vitro da amoreira-preta (Rubus sp.), cultivar Caigangue. Agropecuária de Clima Temperado, Pelotas, v. 3, n. 2, p. 123-130, 2000.

DONNELLY, D. J.; STACE-SMITH, R.; MELLOR, F. C. In vitro culture of three Rubus species. Acta Horticulturae, Wageningen, n. 112, p. 69-75, 1980.

EARLE, E. D.; LANGHANS, R. W. Propagation of Crysanthemum in vitro: II. production, growth and flowering of plantlets from tissue culture. Journal of American Society for Horticultural Science, Alexandria, v. 99, n. 4, p. 352-358, 1974.

FERREIRA, D. F. Análises estatísticas por meio do Sisvar para Windows versão 4.0. In: REUNIÃO ANUAL DA REGIÃO BRASILEIRA DA SOCIEDADE INTERNACIONAL DE BIOMETRIA, 45., 2000, São Carlos. Anais... São Carlos: UFSCar, 2000. p. 255-258.

FORNI, R. C.; PASQUAL, M. Influência da citocinina BAP e concentrações dos componentes do meio "MS" na micropropagação do café 'Catuaí'. Ciência e Agrotecnologia, Lavras, v. 20, n. 4, p. 468-474, 1996.

GEORGE, E. F.; SHERRINGTON, P. D. Plant propagation by tissue culture. Eversley: Exegetics, 1984. 709 p.
GRATTAPAGLIA, D.; ASSIS, T. F.; CALDAS, L. S. Efeito residual de BAP e NAA na multiplicação e enraizamento in vitro de Eucalyptus. In: SIMPÓSIO NACIONAL DE CULTURA DE TECIDOS VEGETAIS, 2., 1987, Brasília, DF. Resumos... Brasília, DF: [s.n.], 1987. p. 10.

LEE, H. J.; KO, K. C. Effects of culture media and plant hormones on shoot tip culture of Fuji apple cultivar (Malus domestica). Seoul National University Journal of Agricultural Sciences, Seoul, v. 9, n. 1, p. 67-77, 1984.

MURASHIGE, T.; SKOOG, F. A revised medium for rapid growth and bioassays with tobacco tissue cultures. Physiologia Plantarum, Copenhagen, v. 15, p. 473497, 1962.

NAVES, V. C. Propagação in vitro da bromélia imperial [Alcantarea imperialis (Carriére) Harms]. 2001. 64 p. Dissertação (Mestrado em Fitotecnia) - Universidade Federal de Lavras, Lavras, 2001.

OLIVEIRA, P. D. Propagação in vitro de crisântemo (Dendranthema grandiflora Tzlev.) cv. Orange Reagen. 1994. 116 f. Dissertação (Mestrado em Fitotecnia) - Escola Superior de Agricultura de Lavras, Lavras, 1994.

PAIVA, P. D. O.; MAYER, M. B. D.; CAMPOS, R. J. C.; RODRIGUES, V. A.; PASQUAL, M. Propagação in vitro de gloxínia. Revista Brasileira de Horticultura Ornamental, Campinas, v. 3, n. 2, p. 29-41, 1997a.

PAIVA, P. D. O de; JOSÉ, S. C. B. R.; PASQUAL, M.; PAIVA, R. Efeito do ácido naftaleno acético e $\mathrm{GA}_{3}$ na micropropagação de violeta. Revista Ceres, Viçosa, v. 44, n. 254, p. 392-398, 1997b.

PASQUAL, M.; ALVES, G. P.; DUTRA, L. F.; FINOTTI, D. R.; CHAGAS, E. A. Cultivo in vitro de embriões imaturos de tangerina 'Poncã': concentrações do meio MS e da sacarose. Revista Ceres, Viçosa, v. 49, n. 282, p. 181-189, 2002.

RASEIRA, M. do C. B.; SANTOS, A. M. dos; MADAIL, J. C. M. Amora-preta: cultivo e utilização. Pelotas: EMBRAPA-CNPFT, 1984. 20 p. (Circular técnica, 11). 
REZENDE, M. E. de. Multiplicação in vitro de Kiwi [Actinidia deliciosa (A. Chevalier) Liang e Fergunson var. deliciosa] cvs. 'Hayward' e 'Matua': influência de concentrações do meio MS e sacarose e de níveis de ágar e pH. 1996. 71 f. Dissertação (Mestrado em Fitotecnia) Universidade Federal de Lavras, Lavras, 1996.

SAKUTA, M. Effects of nitrogen source on betacyanin accumulation and growth in suspension culture of Phytolacca americana. Physiology Plantarum, Copenhagen, v. 71, p. 459-463, 1987.
SKIRVIN, R. M.; CHU, M. C.; GOMEZ, E. In vitro propagation of Thornless trailing blackberries. HortScience, Alexandria, v. 16, n. 3, p. 310-312, 1981.

SRISKANDARAJAH, S.; MULLINS, M. G.; NAIR, Y. Induction of adventitions rooting in vitro in difficult to propagate cultivars of apple. Plant Science Letters, Limerick, v. 24, p. 1-9, 1982.

TAIZ, L.; ZEIGER, E. Plant physiology. Redwood City: The Benjamin Cummings, 1991. 559 p. 